\title{
CONSTITUTIONAL STORM IN INDIA
}

\author{
By S. C. SeN
}

Legal and judicial world in India was recently rocked by a constitutional storm of great severity. The storm had its genesis in what was originally a purely legal battle of constitutional law. The political crisis enhanced its dimension to a battle between the supremacy of the Constitution and the factual supremacy of the Lok Sabha (Lower House of the Parliament). In this storm joined the turbulance of the conflict between constitutionalists and populists and also the conflict between socialists and free enterprises. In totality the storm became a tornado. When the tornado passed over it left behind in its trail a shattered and divided legal profession, a badly shaken and somewhat devalued judiciary and three eminent judges of the Supreme Court of India superseded who ultimately resigned in protest.

\section{Genesis}

Genesis of the whole thing was purely a legal question of constitutional law, namely, whether the fundamental rights entrenched in the Constitution of India could be altered or amended by the Parliament. A short history of the constitutional position and the legal developments will clarify the question.

\section{Fundamental Rights}

Prior to the Indian Constitution coming into existence in 1947 a Constituent Assembly had been convened which had long deliberations over framing the Constitution of India. In the final Constitution a chapter was incorporated which consisted of the Fundamental Rights. (Part III of the Constitution of India, Articles 12 to 35.) Fundamental rights provided for the right of equality before law, prohibition of discrimination on grounds of religion, race, caste, sex, or place of birth, freedom of speech and expression, freedom of movement throughout India and right to reside, settle and hold property in any part of India, to practice any profession or to carry on any occupation, trade or business, protection of life and personal property, freedom of conscience and free profession, practice and propagation of religion, and also of right to property. The chapter on fundamental rights also contained the right to move the Supreme Court for constitutional remedies and the Supreme Court has powers on the Constitution to issue writs in the nature of habeas corpus, mandamus, prohibition, quo warranto, certiorari whichever may be appropriate for the enforcement of any of the fundamental rights ${ }^{1}$. The Constitution of India also includes some provision for amendment of the Constitution in Part XX, Article 368 of the Constitution. The Article provides that an amendment of the Constitution may be initiated by the introduction of a Bill in either House of the Parliament and when the Bill is passed in each House

\footnotetext{
$1 \mathrm{Vgl}$. H. v. Wedel. Grundlagen des Verwaltungsrechtsschutzes in Indien, VRU 1970, S. 487 ff.; ders., Die Verwaltungsklage in Indien, VRU 1971, S. 429.

A.I.R = All India Reporter (Law Reports).

S.C. = Supreme Court Series.
} 
by a majority of the total membership of the House and by a majority of not less than two-thirds of the Members of the House present and voting it shall be presented to the President for his assent and upon such assent being given to the Bill the Constitution shall stand amended in accordance with the terms of the Bill. The fundamental rights entrenched in the Constitution were popularly believed to have been the incorporation of basic human rights and as such unalterable. In the Book "Indian Constitution - Cornerstone of a Nation" by Granville Austin, the scope, origin and the object of fundamental rights have been graphically stated. Therein the learned author says:

"... the core of the commitment to the social revolution lies in Parts III and IV, in the Fundamental Rights and in the Directive Principles of State Policy. These are the conscience of the Constitution."

Adverting to the necessity for incorporating fundamental rights in a Constitution, the learned author says:

"That a declaration of rights had assumed such importance was not surprising; India was a land of communities, of minorities, racial, religious, linguistic, social and caste. For India to become a state, these minorities had to agree to be governed both at the Centre and in the provinces by fellow Indian-members, perhaps, of another minority - and not by a mediatory third power, the British. On both psychological and political grounds, therefore, the demand for written rights - since rights would provide tangible safeguards, against oppression - proved overwhelming."

Motilal Nehru, who presided over the Committee called for by the Madras Congress resolution, in May, 1928 observed in his report:

"It is obvious that our first care should be to have our Fundamental Rights guaranteed in a manner which will not permit their withdrawal under any circumstances ... Another reason why great importance is attached to a Declaration of Rights is the unfortunate existence of communal differences in the country. Certain safeguards are necessary to create and establish a sense of security among those who look upon each other with distrust and suspicion. We could not better secure the full enjoyment of religious and communal rights to all communities than by including them among the basic principles of the Constitution."

Pandit Jawaharlal Nehru, on April 30, 1947 in proposing the adoption of the Interim Report of Fundamental Rights, said thus:

"A fundamental right should be looked upon not from the point of view of any particular difficulty of the moment, but as something that you want to make permanent in the Constitution. The other matter should be looked upon - however important it might be - not from this permanent and fundamental point of view, but from the temporary point of view."

Pandit Jawaharlal Nehru, who was Prime Minister at that time and who must have had an effective voice in the framing of the Constitution, made this distinction between fundamental rights and other provisions of the Constitution, namely, the former were permanent and the latter were amendable. On September 18, 1949 Dr. Ambedkar in speaking on the amendment proposed by Mr. Kamath to Art. 304 of the Draft Constitution corresponding to the present Article 368, namely, "Any provision of this Constitution may be amended, whether by way of variation, addition or repeal, in the manner provided in this article", said thus:

"Now what is it we do? We divide the articles of the Constitution under three categories. The first category is the one which consists of articles which can be amended by Parliament by a bare majority. The second set of articles are articles which require two-thirds majority. If the future Parliament wishes to amend any particular article which is not mentioned in Part III or Article 
304, all that is necessary for them is to have two-thirds majority. Then they can amend it."

Therefore, in Dr. Ambedkar's view the fundamental rights were so important that they could not be amended in the manner provided by Art. 304 of the Draft Constitution, which corresponds to the present Art. 368.

The Constitution in Article 13(2) provided that the State shall not make any law which takes away or abridges the rights conferred by Part III, i. e., the part on fundamental rights, and any law made in contravention of this clause to the extent that the contravention shall be void.

\section{Are Fundamental Rights Alterable?}

The question whether fundamental rights could be altered by the Parliament by reason of the powers contained for amendment under Article 368 for the first time came up before the Supreme Court of India in the case of Shankari Prasad vs. Union of India (AIR*1951 SC 458). The view of the Supreme Court proceeded on the ground that such an act would not come under the expression "law" in Article 13(2) for such expression is only applicable to a legislative measure and not to a constituent measure as an amendment of the Constitution would obviously be. The above view was confirmed by the Supreme Court in the case. of Sajjan Singh vs. State of Rajasthan (AIR 1945 SC 845).

\section{Politics in the legal world}

What was originally a purely legal question of constitutional law, however, suddenly assumed great importance as a result of certain political storms in India. I.al Bahadur Shastri, the Prime Minister of India, died in Tashkent after finalising the Indo-Pakistani Peace Treaty which was necessary after the Indo-Pakistani conflict of 1965. This was in January 1966. The battle of succession for the office of the Prime Minister started. On the one hand, G. L. Nanda was the contestant and he was already the officiating Prime Minister of India. On the other hand, the big bosses of the ruling party, the Indian National Congress, held the main power. (The ruling clique was popularly known as the "Syndicate".) The Syndicate did not support Nanda, and Sm. Indira Gandhi, daughter of Pandit Jawaharlal Nehru, the former Prime Minister of India, was made the Prime Minister of India. At that point of time she was holding only a minor ministry in India. The relationship between Mrs. Gandhi and the Syndicate was not very cordial after some time and rifts began to appear quite clearly. Mrs. Gandhi had suggested the question of nationalisation of banks ${ }^{2}$ ) which was not supported by the Syndicate. It was quite clear that a trouble was bound to come in between Mrs. Gandhi and the Syndicate. Nationalisation of banks was also opposed on the ground that parliament had no powers to alter fundamental rights or to take over property without full compensation.

2 Vgl. B.-O. Bryde, Die Bankverstaatlichung in Indien, VRO 1970, S. $195 \mathrm{ff}$. 


\section{Golak Nath's case}

In 1967 the question of Parliament's right to alter fundamental rights was again taken to the Supreme Court of India in what is now known as Golak Nath's case (AIR 1967 SC 1643). In Golak Nath's case the Supreme Court revised its previous views and overruled the previous cases. In Golak Nath's case the Supreme Court held that the word "law" in Article 13(2) of the Constitution would not only cover a legislative measure but also a constituent measure so that the Parliament had no power under Article 368 to take away or abridge any of the fundamental rights in Part III of the Constitution. Decision of the Supreme Court in Golak Nath's case also proceeded on the ground that Article 368 related only to the procedure for amending the Constitution but did not confer on the Parliament any power to do so. The provisions for fundamental rights also included the rights of property. The position after Golak Nath's case was that the Parliament did not have the right to take away any property rights of a citizen. The Supreme Court had already previously held in Bela Banerjee's case that compensation for any property taken away by the Government will have to be the just equivalent of the value of the property. The position, therefore, became that the Government could not effect any nationalisation or take away any properties without giving as compensation the just equivalent of the value of the properties taken away. Golak Nath's case was thus a victory for the antinationalisation lobby.

\section{Victory of Mrs. Gandhi}

In the meantime, there had been a complete rift between Mrs. Gandhi and the Syndicate of the Indian National Congress, the ruling party. In the struggle for power Mrs. Gandhi's party proved to be much stronger and she got almost complete control of the ruling party. General Election was held in India in 1968 as a result of which Mrs. Gandhi came in with a vast majority and the opposing Syndicate group was almost eliminated. In the election manifesto of Mrs. Gandhi's party nationalisation of banks was one of the items. Thereafter, several amendments of the Constitution of India were effected by the Parliament by virtue of the powers given under Article 368 of the provisions of the 24th, 25th, 26th amendment of the Constitution changes made of the fundamental rights. By the amendments the Parliament assumed the power to nationalise and take away properties without providing for just equivalent as compensation. The question however, still remained whether the amendments of the Constitution effected by the Parliament by virtue of powers under Article 368 were by valid exercise of such powers or whether such amendments themselves were invalid.

\section{Nationalisation of banks challenged}

In 1969 provisions were introduced by the Government of India for nationalisation of banks and banks were taken over by the Government of India pursuant to such ordinances or acts. These measures by the Government were challenged and taken before the Supreme Court in what is popularly known as the Bank Nationalisation case (R. S. Cooper vs. Union of India: AIR 1970 SC 564). In this 
case the Supreme Court followed the principles of Golak Nath's case and held that nationalisation or compulsory taking away of property without just equivalent as compensation was violative of the constitutional guarantees given by the fundamental rights and as such stopped down the measures introduced by the Government. Subsequently, however, new legislations were enacted and the banks obtained a much bigger amount as compensation for the properties taken over.

\section{Princes' case}

The Bank Nationalisation case was a victory for the free enterprisers and a blow for the lobbyists for nationalisation without adequate compensation. The matter, therefore, created a lot of political conflict. The already hot political arena became hotter with the next case. This was he case of the Princes. When the British came to India there was a large number of small and big principalities and independent rulers who used to rule over them. By and under various treaties the British had obtained the sovereignty from them and there were regular treaties in most of these cases. These treaties were considered to have been treaties between independent sovereign monarchs. After the independence of India all these states joined the Union of India under documents known as Instruments of Accession. With the Instruments of Accession the rulers of the Native States surrendered their rights and privileges and sovereignty, if any, over their states and in exchange they got various new privileges. These privileges were guaranteed by articles 291, 362 of the Constitution. The most important of these privileges was the annual payment of an amount of money called the Privy Purse.

Payment of the Privy Purse involved a sizeable payment from the Indian Exchequer to the rulers who also thereby formed a privileged class. The socialists and communists had for a long time agitated for abolition of the Privy Purse and stoppage of payment to these rulers. There had been negotiations for gradual scaling down and ultimate abolition of the Privy Purse but none of these negotiations had succeeded. Payment of the Privy Purse and continuance of the privileges were guaranteed under the Constitution of India itself. During 1967 the Indian Congress Committee passed a resolution for abolition of the Privy Purse. After the breakdown of negotiation with the Princes the Government of India acted rapidly. The President in his speech to the Houses gave expression to the policy of Government. A Resolution recommending the abolition was moved and passed in the Rajya Sabha. A Bill was then moved in the Lok Sabha entitled.

The Constitution (Twenty Fourth Amendment) Bill 1970.

It consisted of three clauses and a short statement of Objects and Reasons. The Statement read:

"The concept of rulership, with Privy Purses and Special Privileges unrelated to any current functions and social purposes, is incompatible with an egalitarian social order. Government have therefore decided to terminate the Privy Purses and Privileges of the Rulers of former Indian States. Hence this Bill."

The address of the President to the Joint Session of Parliament, the Resolution referred to above and the Statement of Objects and Reasons all gave identical reasons. The Bill was voted upon in the Lok Sabha on September 2, 1970. 332 
votes for and 154 votes against it were cast. It was considered in the Rajya Sabha on September 5, 1970 and was defeated, 149 voting for and 75 against it. It thus failed in the Rajya Sabha to reach the requisite majority of not less than twothirds of the members present and voting.

The Bill originally gave no indication of the date when the Act was to come into operation but in the Lok Sabha an amendment was accepted by which it was to come into force from October 15, 1970. By the second clause the Bill omitted Articles 291 and 362 of the Constitution and the third clause omitted Article $366(22)^{3}$. The same evening the Cabinet is said to have met and to have decided to advise the President to withdraw the recognition of the Rulers. The same night the President signed an instrument at Hayderabad withdrawing recognition of all the Rulers. Separate orders were issued to all the Rulers on the 6th September 1970 and they were notified in the Gazette as already mentioned.

All the rights and privileges of the Princes including their right to Privy Purse was therefore abrogated by a stroke of the pen. Inevitably the matter was taken to court in the reported case of Maharajadhiraj Madhab Rao Jivaji vs. Union of India (AIR 1971 SC 530), popularly known as the Prince's Case.

In this case the Princes who were now citizens of India asserted their constitutional rights guaranteed by the constitutional guarantees entrenched in the Constitution of India. Again the Supreme Court followed the principles of Golak Nath's case and upheld the fundamental rights guaranteed by the Constitution of India. This was thus another clear victory for the antinationalisation lobby.

\section{The storm}

Although by various other steps the Government withheld payment of Privy Purse to the Princes nonetheless the case was a further set-back to the socialists and was a further victory for the so-called rightists or free enterprisers and constitutionalists. The storm now came in full force with demands for setting aside all impediments to full nationalisation. In the heat of the political battle the cry emerged that unless Golak Nath's case was set aside the Government was incapable of introducing further "Progressive Measures" and the progress of the nation towards socialism would be hampered. In the battle cry the communists stated from time to time that the Judges all came from a particular class background and they questioned even the suitability of such Judges to dispense justice. They openly criticised the Judges as reactionary and anti-government. The constitutional and legal battle was given fully political tilt and frequently formed the subject matter in political debates. There was frequent cry that Golak Nath's case was wrongly decided and should be set aside. In fact the bench consisted of 11 Judges and the majority view consisted ob 6 Judges as against 5 who dissented. Suggestions were even made by some for packing the Supreme Court with new Judges who would have the same views as that Government. The political battlecry came "Golak Nath's case Must Go". No one was certain as to what steps the Government would take to nullify the decision in Golak Nath's case.

3 This article gives the definition of the term "Ruler*. 


\section{Golak Nath's decision challenged}

In this heated atmosphere matters were taken to Supreme Court once again for overruling the decision in Golak Nath's case. This was in the case of His Holiness Keshavananda Bharati vs. State of Kerala and others (AIR1973 SC 1461). In view of the importance of the matter the full court of the Supreme Court consisting of 13 Judges sat over the matter. Many of the big guns of the Indian legal profession were appearing in the matter and outside court there was great speculation as to what was going to happen. Unwillingly the Supreme Court had become the centre of the political controversy. The matter was argued at length for months altogether and all other work of the Supreme Court was virtually stopped. While the matter was being argued in the Supreme Court the debate raised by the politicians outside the legal world was much stronger and was of much more intensity. To the average people the main legal issue had become completely clouded by the debate raised by the conflicting political parties. It was frequently speculated as to what was going to happen if the Supreme Court stuck to the views expressed in Golak Nath's case. It was suggested and threatened by some that Government should take steps to increase the number of Judges in the Supreme Court of India and fill it up with such persons who would agree with the views of the Government of India. Government, however, had not appointed any such Judges nor had put in any proposal for increasing the number of Judges in the Supreme Court. In the surcharged atmosphere judgment was ultimately delivered by the Supreme Court after a very prolonged hearing. In fact the judgment was speeded up to a certain extent because the Chief Justice of India, Chief Justice Sikri, was to retire. The full court re-assembled on the day before his retirement to deliver the judgment. In view of the judgment being very voluminous the Judges first pronounced a summary of the views of the majority of the bench. The summary was signed by 9 of the 13 Judges including the Chief Justice. Even the other Judges had not differed on the main points but they had other views to propound. The summary of the judgment as propounded by the Supreme Court was as follows:

"SUMMARY

The view by the majority in these writ petitions is as follows:

1. Golak Nath's case is overruled;

2. Article 368 does not enable Parliament to alter the basic structure or framework of the Constitution;

3. The Constitution (Twenty-fourth Amendment) Act, 1971 is valid;

4. Section 2(a) and 2(b) of the Constitution (Twenty-fifth Amendment) Act, 1971 is valid;

5. The first part of Section 3 of the Constitution (Twenty-fifth Amendment) Act, 1971 is valid. The second part, namely, 'and no law containing a declaration that it is for giving effect to such policy shall be called in question in any Court on the ground that it does not give effect to such policy' is invalid;

6. The Constitution (Twenty-ninth Amendment) Act, 1971 is valid.”

It was a clear victory now for Government and a clear victory for the socialists and communists. All the insinuations and allegations regarding the Judges being rightists were proved to be incorrect. There was great jubilation and celebration by the propounders of the so-called "Progressive Measures". It was expected that now the storm would die down and the courts would start functioning again away 
from publicity, away from political conflict and in the peaceful isolation in which courts of law find it easier to function. Little did people know that there were to be more dramatic developments.

\section{High Drama of Supersession of Judges}

Judgment of the Supreme Court in Keshavananda's case was delivered on the 24th April 1973. Chief Justice Sikri was to retire on the 25th April 1973 and a new Chief Justice was to take office after his retirement. From the very beginning of the establishment of the Supreme Court of India the seniormost Judge had always been appointed the Chief Justice of India. Only once it was suggested that the second seniormost Judge be appointed instead of the seniormost Judge who was the acting Chief Justice and all the Judges had threatened to resign including the Judge who was due to be appointed Chief Justice. Since then this was considered to be a settled convention that the seniormost Judge of the Surpreme Court would be the Chief Justice. After Chief Justice Sikri the three seniormost Judges were Justice Shelat, Justice Hegde and Justice Grover. Justice A. N. Ray was the next Judge in seniority. It was expected that formal announcement would be made appointing Justice Shelat the Chief Justice of India. He was, however, to have a short tenure as he was to retire in a few months time. Justice Hegde was to have then his turn as Chief Justice for about a year. Then Justice Grover was to have about a three-year tenure. Justice A. N. Ray was due to retire before Grover. So, there was no chance of his ever becoming the Chief Justice of India.

On the 25th April 1973 Justice Hegde was listening to the news broadcast from Delhi at 5 p. m. He heard the following announcement:

"The President has appointed Mr. Justice Ajit Nath Ray to be the Chief Justice of India with effect from the 26th of this month on the retirement of Mr. Justice S. M. Sikri."

The announcement came as shock. Never before in the history of India had Judges of the Supreme Court been superseded in the appointment of Chief Justice. In the instant case 3 seniormost Judges were superseded. It was clear that the gods of politics had claimed their victims.

The three superseded Judges got into a hurried conference. They decided to take a day's leave pending their decision as to whether they will resign. They refused to attend the ceremony for the swearing in of the new Chief Justice. At the end of another day they put in their resignations from the office of Judges of the Supreme Court of India. Resignations were accepted and the President's Secretary sent a brief note formally accepting the resignations without using the words "with regret". It was rumoured that the President was unwilling first to appoint a Chief Justice by superseding the three seniormost Judges but ultimately agreed to do so on the advice of his Ministers. It was further rumoured that the President wanted to acknowledge the letters of resignation personally and accept them "with regret" but the Home Secretary opposed the move and the Law Minister advised that such a step would not be in consonance with either the letter or the spirit of the Constitution. Even the use of the words "with regret" was opposed by the Home Ministry and as such ultimately dropped. 
Slowly more details came out. On the 24th April 1973 at 10 a. m., a few hours before the judgment of the Supreme Court was announced, the Political Affairs Committee of the Cabinet had assembled and decided to appoint Justice Ray as the Chief Justice by superseding the three senior Judges. Kumaramangalam, the Minister of Mines and Steel (a former communist turned Congress) was the moving spirit for this decision. He was of course supported by certain others including the Law Minister of India. The Chief Justice of India was not consulted about his successor although this had been the invariable practice so far. The President of India originally was not happy about the supersession but ultimately he did not make an issue out of it. The supersession was a political decision. There was no allegation of any moral turpitude against any of the superseded Judges. They were all Judges of great ability but it appeared that the views of some of the Judges were not acceptable to some politicians.

The legal profession reacted vehemently. Under the direction of the Supreme Court Bar Association "Bar Solidarity Day" was observed throughout the country. Lawyers all over the country boycotted the courts that day. The first day after the appointment of Justice Ray as the Chief Justice of India most lawyers refused to attend the court. Banners were displayed "Boycott Court"; "Save Judiciary and Democracy". On the other hand, Lawyers belonging to communist parties and some belonging to the party in power (Congress) demonstrated great jubilation. Icecreams were distributed by some within the compound of the Supreme Court of India to celebrate "a happy event".

By and large, the action of the Government in superseding the Judges was found unacceptable to the vast majority of lawyers. Independence of the Judiciary was considered to be in peril. Eminent lawyers including former Attorneys General issued statements calling it "The Saddest Day in the History of Our Free Institutions". Some called it "Subversion of the Constitution from within". N. A. Palkhivala, a leading lawyer, edited a pamphlet collecting protest from all over the country under the title "A Judiciary made to Measure". All over the country there were protests by associations of lawyers. The Supreme Court Bar Association convened an All India Convention of Lawyers on the Independence of the Judiciary. Resolutions were passed by various associations of lawyers condemning the action of the Government. Almost all spokesmen however made it clear that they had nothing against Justice A. N. Ray but it was the action of the Government that they were opposing.

Counter-conventions were also organised by lawyers belonging to communist parties as also by some lawyers belonging to the party in power. It was a happy event because it would be the end of bourgeois dominated judiciary. In the heat of the battle invectives were thrown by the opposing parties at each other. Temperance of language became a main casualty.

Almost all the leading lawyers and jurists of India condemned the action of the Government although all of them made it clear that they had nothing against Chief Justice Ray.

Ministers by their speeches added fuel to the fire. Kumaramangalam in his speech in the Parliament on the 12th of May 1973 stated that Government had to take into account the Judges' basic outlook on life. "We as a Government have a duty to take into account the philosophy and outlook of a Judge in coming to the conclusion whether he should or should not lead the Supreme Court at this time. This is our own prerogative." 
M. C. Setalvad, a former Attorney General of India and a higly respected jurist and lawyer, commented about Kumaramangalam's statement as follows:

"The real issue is not so much the supersession of the three eminent Judges as the principles laid down by Minister Kumaramangalam. The selection of the Chief Justice in future, namely that he has to be a person whose social philosophy conforms to that of the ruling Government of the day. To my mind, it is that principle which threatens the independence of the judiciary all over the country."

The representatives of four political parties, Congress (Organisation), Jana Sangh, Swatantra and DMK, submitted a memorandum to the President "to restore the faith of the people in the independence of the judiciary". Even to many congressmen the statement made by Kumaramangalam was considered to be an overstating of the Government's case. Law Minister Gokhale tried to retrieve the situation. $\mathrm{He}$ said "I have no hesitation in saying that the Government is not interested in having committed Judges in the sense in which the word has come to be used and understood now. More than anyone else the Government is very keen and will see to it that India will have a strong and independent judiciary and the Judges will function according to their oath without fear, ill-will, affection or favour."

Kumaramangalam himself tried to undo some of the mess he had brought in by overstatement. Instead of the Judges' philosophy he now talked of constitutional philosophy. In a speech delivered on the 14th of May he stated that the Government did not want to have in the Supreme Court Judges who were subservient to the Executive. The crux of the issue was the supremacy of the Parliament and the Government was determined to assert it in terms of the Constitution itself. In the process of saying so Kumaramangalam however brought in another dangerous doctrine. Was it now to be assumed that the supremacy of the Constitution was gone and the supremacy of the Parliament established instead? This was a question which was again objected to by various people. Kumaramangalam was a confirmed Marxist and communist. He had only recently left the Communist Party and joined the Congress. He had still asserted his continued belief in Marxism and had openly advocated that the Congress Party should accept Marxist philosophies and economic policies. Close subservience of the judicial machinery to the dominant political ideology was a part of his get-up. Assurances coming from him did not do much to convince the people of the Government's intention to continue the independence of the judiciary. Lawyers generally were not prepared to accept assurance from Kumaramangalam which they would have accepted from the Prime Minister of India.

The statements by the Ministers and some leading members of the party in power however made it clear that the three Judges were superseded because he Government had not agreed with their views. To some it appeared that it was an assertion of strength by the Government and a warning to Judges as to their future conduct. The independence of the judiciary certainly looked like having had a bad jolt.

A comic touch was introduced in the tense scene by the reported statement of the Congress President Shankar Dayal Sharma (who became very angry over the lawyers' protests) that the legal profession should be nationalised. Sharma however promptly claimed that he was misquoted.

The battle went on for some time. There were fiery speeches in the Parliament as also outside. There were demonstrations and counter-demonstrations, con- 
ventions and counter-conventions. As is natural, the movement has lost most of its momentum and the courts of India are functioning normally again. Chief Justice Ray continues to function as the Chief Justice of India and there have not been any comments about him from the profession and no one has accused him of not acting with dignity and fairness. His task however has not been made easy by intemperate language used by politicians from time to time.

\section{Epilogue}

The storm has blown over and high drama has come to an end. But it did not end without elements of further drama. Minister Kumaramangalam, the most militant supporter of the supersession of the Judges, was now the new power. Over night he nationalised all the coal mines in India. His power now extended over all steel mills and over all coal mines and he was thus the most powerful Minister apart from the Prime Minister. His supporters now termed him "the Deputy Prime Minister". Kumaramangalam was not a modest man. He was travelling all over India exuding contempt for the opposition. To justify his stand on the supersession of the Judges, Kumaramangalam published a pamphlet called "Judicial Appointments". In this he gave his analysis of the controversy over the appointment of the Chief Justice of India. The pamphlet was to be marketed with great fanfare. On the evening before the day when the pamphlet was to be marketed he was coming back from Madras to Delhi by plane. The person in charge of marketing was to receive him at the airport with a copy of the printed pamphlet. With a dramatic ending his plane crashed within a few miles of the Delhi airport and Kumaramangalam died. Some called it "a grave loss to India", some called it "Nemesis". Attempt was made by some lawyers to instal in Madras High Court a portrait of Kumaramangalam and they had invited the Prime Minister of India to inaugurate the portrait. There was violent protest from the Madras Bar Association which stated that it had not at all asked the Prime Minister to come and condemned the attempt to hang that portrait. The portrait was not hung afterall. 
investment of drafting skill contained in some British statutes. Of arguments against their application, the strongest seems to be that statutes designed for Britain are unlikely to be suitable for Ghanaian society. The present trend away from the application of British statutes per se, and towards the incorporation of their texts in Ghanaian enactments, suggests that the two arguments mentioned are decisive in decision-making today.

\section{Constitutional Storm in India}

BY S. C. SEN

India has recently had its greatest constitutional crisis since its independence in 1947. The Indian Constitution was framed in 1947 on a strong democratic base. The Constitution enshrined in a special chapter fundamental human rights which were considered to be inalienable. A strong Supreme Court rich in democratic traditions successfully functioned in India and was the guardian of constitutional rights.

The constitutional peace and tranquility and the democratic structure and the supremacy of the rule of law was recently the subject of a nationwide debate in India. Originating as a purely legal question it became both a political as well as legal issue. Supremacy of the Constitution, powers of the Parliament and independence of the judiciary all became subject-matter of the great debate. After a historic decision of the Supreme Court three judges of the Supreme Court of India were superseded and resigned in protest and lawyers were in revolt all over the country. An element of high dramatic tragedy was introduced when a Cabinet Minister who most vocally supported the supersession of judges died in an air crash. The article describes in detail the whole episode and its implications.

\section{Elections for President in Turkey March-April 1973}

\section{By G. Papadimitriu}

The article deals with the provisions about the election of the Turkish President. On this background, the facts of the Turkish presidential election in Spring 1973 are presented. The author then reviews the constitutionality of this election. He concludes that the military has - in violation of the language and the spirit of the constitution - attempted to manipulate the election by reducing the choice of the competent organ (The Great Turkish National Assembly) to one person sympathetic with the views of the military. However, the author does not go along with assumption that the election was in toto unconstitutional; such a verdict would be, in his opinion, simplifying and formalistic. This judgement is supported by some remarks about the ongoing factual constitutional process of revision as highlighted by the described election. These remarks clearly point to the weakening of the liberal and democratic character of the 1961 constitution; conservative features with reactionary elements are obvious. 